\title{
Analisis Strategi Peningkatan Industri Makanan Ringan di Kota Payakumbuh
}

\author{
Mustika Lukman Arief \\ mustikalukmanarief@rocketmail.com \\ Akademi Maritim Sapta Samudra Padang \\ Dorris Yadewani \\ dorris290@gmail.com \\ Akademi Manajemen Informatika dan Komputer Jayanusa Padang
}

\begin{abstract}
This study aims to determine the development of the snack industry in Payakumbuh City and the strategies needed to develop it. The research method used is social research and literature research. The analysis used is SWOT analysis. SWOT analysis, resulting in strategies as well as the position of the snack industry, obtained 9 strategies, such as : (1) Optimizing Production, (2) Market Expansion Strategy, (3) Strategy for Innovation and Utilization of Technology in Production, (4) Product Development Strategy, (5 ) Partnership Development Strategy, (6) Government Guidance and Training Strategy, (7) Industrial Estate Development Strategy, (8) Product Quality and Competitiveness Improvement Strategy and (9) Snack Product Marketing Strengthening and Development Strategy
\end{abstract}

Keywords : SME'S, strategy, SWOT

\section{Pendahuluan}

Sebagai pendorong gerak pembangunan dan perekonomian, seyogyanya Usaha Mikro Kecil dan Menengah (UMKM) mendapat fokus perhatian dan pembinaan yang serius. Usaha produktif milik orang perorangan dan/atau badan usaha perorangan yang memenuhi kriteria Usaha Mikro sebagaimana diatur dalam Undang-Undang (Undang-Undang No 20 Tahun 2008 Tentang Usaha Mikro, Kecil Dan Menengah). Pengaruh dari pengembangan UMKM di Indonesia dan melihat peran serta pemerintah dalam meningkatkan pertumbuhan UMKM di Indonesia memiliki hasil positif, baik secara langsung maupun tidak langsung (Tambunan, Tulus, 2009)

Mudrajad (2003), memaparkan tentang karakteristik UMKM secara umum yaitu : sistem pembukuan yang sederhana, margin usaha yang cenderung tipis dengan modal terbatas, minimnya pengalaman manajerial dalam mengelola perusahaan dengan skala ekonomi yang terlalu kecil, keterbatasan kemampuan pemasaran dan negosiasi. Namun sisi lainnya, sektor UMKM juga tak luput dari sentra masalah, terutama bila dilihat dari segi prioritas permasalahannya. Secara umum permasalahan yang paling banyak dihadapi oleh pengusaha UMKM adalah masalah kurangnya modal, yakni sebesar 45\%, disusul kemudian masalah kurang terampilnya sumber daya manusia, masalah bahan baku juga termasuk permasalahan serius, ini menempati tingkat permasalahan rangking tiga, yakni sebesar 4\%. Masalah lainnya seperti persaingan, lokasi, perijinan, pemasaran dan lain-lain.

Salah satu pemerintah daerah di Provinsi Sumatera Barat yang berkomitmen dalam memajukan UMKM daerahnya adalah Kota Payakumbuh. Hal ini sesuai dengan visi pembangunan jangka panjang daerah Kota Payakumbuh Tahun 2005-2025 yaitu "Terwujudnya Payakumbuh Sebagai Kota Maju dengan Pengembangan Sentra Usaha Mikro, Kecil dan Menengah" yang akan diwujudkan melalui misi ke-4 yaitu "Mewujudkan sentra Usaha Mikro, Kecil dan Menengah (UMKM) yang produktif dan efisien serta mampu bersaing di dunia global"(RPJMD Kota Payakumbuh Tahun 2017-2022.) 
Kota Payakumbuh terkenal dengan makanan khasnya kalamai dan berbagai makanan khas daerah lain yang berada di Sumatera Barat. Strategi yang paling tepat bagi suatu industri kecil adalah strategi yang disusun dengan mempertimbangkan kondisi industri yang terdiri dari kekuatan dan kelemahan untuk memanfaatkan peluang dan mengantisipasi ancaman yang ada dalam lingkungan yang selalu berubah dan semakin kompetitif (David, 2004).

Strategi adalah perencanaan induk yang komprehensif, yang menjelaskan bagaimana perusahaan akan mencapai semua tujuan yang telah di tetapkan berdasarkan misi yang telah di tetapkan sebelumnya (Rangkuti, 2013). Sementara itu, strategi juga dapat diartikan sebagai sarana bersama dengan tujuan jangka panjang yang hendak dicapai (Fred R. David, 2011). Sehingga dapat diambil kesimpulan, bahwa strategi merupakan sebuah rencana yang dibuat oleh seseorang atau perusahaan untuk mencapai tujuan yang sudah di tetapkan.

Berdasarkan kondisi di atas, dalam penelitian ini akan mengkaji secara mendalam dan komprehensif tentang apa strategi yang diperlukan untuk mengembangkan Industri Mikro dan Kecil di Kota Payakumbuh

\section{Metodologi Penelitian}

\subsection{Data dan Sumber Data}

Jenis data yang dikumpulkan adalah data kuantitatif dan kualitatif baik yang bersifat primer maupun sekunder. Data primer dapat didefinisikan sebagai data yang dikumpulkan dari sumber-sumber asli (Kuncoro, 2003). Data primer dikumpulkan melalui survey lapangan dan wawancara. Data sekunder diperlukan sebagai pendukung data primer, yang didapatkan dari Dinas Koperasi, Perindustrian dan Perdagangan, Bappeda, BPS

Pemilihan sampel dilakukan secara accidental terhadap industri makanan ringan, sebanyak 10 (sepuluh) sampel, dengan kriteria : 1) Sudah melakukan usaha lebih dari 2 tahun secara kontinyu 2) Terdaftar dan pernah mendapat pelatihan. Adapun variabel dalam penelitian ini adalah: 1) Profil IMK makanan ringan Kota Payakumbuh periode 2018 -2019, 2) Strategi pengembangan IMK makanan ringan

Analisa data menggunakan metoda analisis deskriptif berupa perkembangan IMK periode 2018-2019, untuk menganalisa strategi untuk pengembangannya dilakukan dengan uji analisa SWOT. Strategi yang paling tepat bagi suatu industri kecil adalah strategi yang disusun dengan mempertimbangkan kondisi industri yang terdiri dari kekuatan dan kelemahan untuk memanfaatkan peluang dan mengantisipasi ancaman yang ada dalam lingkungan yang selalu berubah dan semakin kompetitif (R. F. David, 2004)

\subsection{Kerangka Pemikiran}

Secara skematik kerangka pemikiran ini dapat dilihat pada Gambar 2.1 berikut ini :
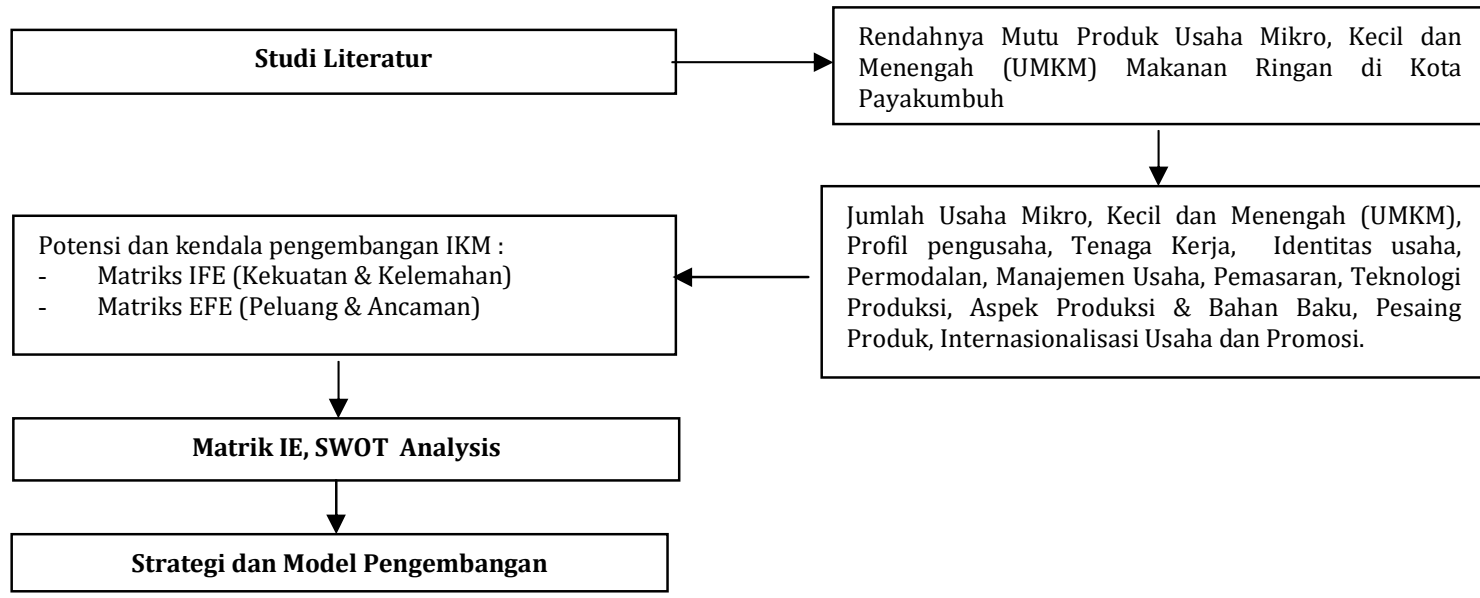

Gambar 1. Kerangka Pemikiran 


\section{Analisis dan Pembahasan}

\subsection{Profil Pengusaha}

a. Pendidikan

Tingkat pendidikannya rata-rata tamat SMA, kondisi ini banyak memberikan pengaruh pada pelaksanaan proses produksi, inovasi dan diversifikasi produk terutama dalam hal pola pikir dan budaya berusaha.

b. Tenaga Kerja

Jumlah tenaga kerja bervariasi, namun sebagian besar antara 5 - 10 orang. Hal ini jauh berbeda dari kriteria Badan Pusat Statistik yang mendefinisikan usaha kecil dimana jumah tenaga kerjanya 5 - 19 orang.

c. Identitas Usaha

Hampir 100 \% UMKM sampel yang diteliti usahanya sudah berbadan hukum. Izin usaha yang mereka miliki diantaranya adalah Tanda Daftar Perusahaan atau Tanda Daftar Industri, SIUP, NPWP, HO dan lainnya. Walaupun belum semuanya mengurus kelengkapan izin usahanya hanya mengurus salah satu dari izin usaha di atas.

Adapun lama usaha ini telah dijalankan berkisar antara 5 - 10 tahun. Rata rata pengusaha UMKM ini melanjutkan usaha yang telah dirintis orang tuanya ,sisanya menjalankan usaha berdasarkan pengalaman kerja yang telah mereka dapatkan sebelumnya dan sebagian kecil memulai usaha dengan coba-coba saja.

d. Permodalan

Struktur modal industri sampel pada tahun 2018 menunjukkan bahwa sebagian besar Usaha Mikro, Kecil dan Menengah (UMKM) makanan ringan ini berusaha dengan menggunakan modal pinjaman. Seluruh sampel industri umumnya telah memanfaatkan jasa pinjaman pada dana bergulir yang dikelola oleh pemerintah.

e. Manajemen Usaha

Pada umumnya belum melakukan pembukuan keuangan walaupun ada itu hanya secara sederhana dan manual dan dibukukan oleh tenaga biasa dan bukan tenaga profesional/tenaga khusus. Disamping itu semua perusahaan yang termasuk ke dalam kategori UMKM ini tidak pernah di audit oleh pihak berwenang.

Transaksi penjualan yang dilakukan tidak seluruhnya kontan, ada yang sistemnya bayar satu tinggal satu, ada yang setengah kontan dan setengah kredit, dan $100 \%$ kredit. Jadi disinilah terjadinya kekurangan modal bagi pengusaha karena pembelian produk mereka secara kredit sedangkan untuk membeli bahan baku secara kontan.

f. Pemasaran Produk

Wilayah pemasaran terhadap produk makanan sudah bisa menembus pasar-pasar regional diluar kota Payakumbuh sendiri, seperti ke Bukittinggi, Padang, sebagian wilayah Sumatera, Batam dan Jakarta. Terlepas untuk memenuhi kebutuhan pasar domestik, Kota Payakumbuh sendiri sudah memiliki LO/Agen pemasaran di Kota Batam yang khusus untuk memasarkan produk-produk makanan khas Payakumbuh di daerah tersebut.

g. Kerjasama Pemasaran Hasil Produksi

Dalam rangka memperluas jangkauan pasar, pemerintah Kota Payakumbuh telah kerjasama atau MOU dengan beberapa Pemerintah Daerah lain

h. Teknologi Produksi

Sejumlah pengusaha masih menggunakan cara tradisional dalam memproduksi produknya, hal ini terlihat dari peralatan-peralatan produksi yang dipakai dalam menghasilkan produk yang masih bersifat sederhana,untuk proses packaging masih sederhana yang hanya digunakan untuk perekat pembungkus dari produk tersebut.Inovasi dalam UMKM masih rendah. Produksi masih dilakukan dengan peralatan yang tradisional dan cenderung tidak berubah dari masa ke masa.

i. Pesaing Produk

Pesaing berasal dari dalam kota, dalam propinsi dan luar propinsi serta dari skala usaha yang berbeda-beda pula mulai dari skala usaha mikro, kecil, menengah sampai usaha 
besar. Sebagian besar perusahaan bersaing dalam mutu, model dan rasa, sedangkan dalam harga mereka cenderung memberikan harga yang sama.

j. Promosi

Promosi yang dilakukan selama ini hanya melalui mulut ke mulut sehingga produk makanan kurang cepat dikenal konsumen.Pemerintah Daerah Kota Payakumbuh melalui Diperindagkop dengan Kegiatan Pengembangan Kelembagaan Kerjasama Kemitraan Tahun 2018, berupaya terus memperkenalkan produk UMKM melalui keikutsertaan dalam berbagai pameran dan bazaar yang berskala lokal dan nasional. Adapun pameran yang telah diikuti selama tahun 2018 adalah sebagai berikut :

1) Pameran Padang Fair

2) Pameran Pangan Nusa di Jakarta

3) Pameran Investrade 2018 Expo dan Forum

4) Temu Mitra/Bisnis di Kota Tanjung Pinang

5) Kegiatan Tukar Informasi dan Pameran Titex di Bali

6) Festifal Kuliner Nusantara di Kota Palembang

7) Kegiatan Pengembangan Kelembagaan Kerjasama Kemitraan (Tindak lanjut pembentukan Agen/Distributor kota Payakumbuh di Jakarta)

8) Temu Mitra/Bisnis di Kota Pekanbaru dan Bangkinang

k. Profitabilitas Usaha

Rata-rata keuntungan sampel per bulannya antara Rp.500.000,- sampai Rp.2,000.000,Hal ini menandakan bahwa usaha di bidang makanan ringan dapat dijadikan sebagai sumber pendapatan utama.

\subsection{Strategi Pengembangan Usaha Mikro, Kecil dan Menengah (UMKM) Makanan Ringan di Kota Payakumbuh}

Analisis internal diarahkan untuk melihat, menginventarisir dan mengkaji faktor-faktor kekuatan dan kelemahan sedangkan analisis eksternal ditujukan untuk melihat, menginventarisir dan mengkaji faktor-faktor peluang dan ancaman bagi pengembangan UMKM di Kota Payakumbuh. Analisis ini didasarkan pada logika yang dapat memaksimalkan dengan SWOT

\subsubsection{Faktor Internal dan Eksternal Pengembangan Usaha Mikro, Kecil dan Menengah} (UMKM) Makanan Ringan di Kota Payakumbuh

Dalam merencanakan pengembangan UMKM makanan ringan terlebih dahulu dilakukan identifikasi terhadap faktor-faktor internal (kekuatan dan Kelemahan) dan eksternal (peluang dan ancaman) yang dimiliki Kota Payakumbuh.

\section{a. Faktor Internal}

1) Unsur Kekuatan (Strengths)

Dari sisi kekuatan, pengembangan industri kecil makanan ringan di Kota Payakumbuh didukung oleh faktor-faktor:

a) Potensi sumber daya bahan baku.

b) Potensi tenaga kerja lokal yang tersedia banyak dan upah yang murah.

c) Kebijakan pemerintah yang sangat mendukung perkembangan industri kecil di Kota Payakumbuh

d) Pembinaan-pembinaan yang dilaksanakan oleh pemerintah Kota Payakumbuh khususnya Dinas Perindagkop maupun upaya promosi dengan membuat kantor penghubung/Agen pemasaran di Kota Batam.

2) Unsur Kelemahan

Dari sisi kelemahan, pengembangan industri kecil makanan ringan di Kota Payakumbuh dipengaruhi oleh faktor-faktor:

a) Kualitas dari produk makanan ringan tersebut yang masih rendah

b) Teknologi yang digunakan dalam produksi yang masih sederhana

c) khususnya masalah packaging.

d) Rendahnya modal usaha.

e) Kemampuan manajemen usaha yang masih rendah. 
f) Kelembagaan pengusaha yang belum optimal terfungsi dalam upaya pembinaan terhadap industri kecil

g) Informasi pasar yang sering terlambat diketahui akibat dari teknologi informasi yang kurang tersedia .

Untuk mengetahui unsur-unsur pada faktor internal yang sangat penting dan strategis bagi pengembangan indutri kecil makanan ringan, maka dilakukan analisis faktor strategi internal dengan menyusun suatu table IFAS (Internal Faktor Analysis Summy)

Tabel 1. Internal Strategic Faktors Analysis Summary (IFAS) Pengembangan Industri Makanan Ringan di Kota Payakumbuh

\begin{tabular}{|c|l|c|c|c|}
\hline No & \multicolumn{1}{|c|}{ Faktor Strategis Internal } & Bobot & Rating & Skor Total \\
\hline A & Kekuatan & & & \\
\hline 1 & Ketersediaan bahan baku & 0,127 & 4 & 0,508 \\
\hline 2 & Ketersediaan Tenaga kerja & 0,112 & 3 & 0,336 \\
\hline 3 & Kebijakan pemerintah & 0,112 & 3 & 0,336 \\
\hline 4 & Pelaksanaan pembinaan & 0,102 & 3 & 0,306 \\
\hline & Jumlah & 0,453 & 13 & 1,486 \\
\hline B & Kelemahan & & & \\
\hline 1 & Kualitas produk & 0,088 & 3 & 0,264 \\
\hline 2 & Penggunaan Teknologi & 0,107 & 3 & 0,321 \\
\hline 3 & Permodalan & 0,083 & 2 & 0,166 \\
\hline 4 & Manajemen Usaha & 0,083 & 2 & 0,166 \\
\hline 5 & Kelembagaan Pengusaha & 0,102 & 3 & 0,306 \\
\hline 6 & Informasi Pasar & 0,083 & 2 & 0,166 \\
\hline & Jumlah & 0,546 & 15 & 1,389 \\
\hline & Total & $\mathbf{1 . 0 0 0}$ & & \\
& & & & \\
\hline
\end{tabular}

\section{b. Faktor Eksternal}

1) Unsur Peluang

Dari sisi peluang, didukung berbagai unsur:

a) Terbukanya peluang pasar yang sangat besar apalagi sejak dibukanya China AFTA

b) Pertumbuhan ekonomi Kota Payakumbuh yang setiap tahun selalu menunjukkan peningkatan yang signifikan

c) Kemajuan teknologi

d) Keragaman produk

2) Unsur Ancaman

a) Ancaman produk sejenis yang lebih tinggi mutunya

b) Selera komsumen yang lebih cendrung pada produk import

c) Inflasi akan menyebabkan harga-harga bahan baku meningkat

Untuk mengetahui unsur-unsur pada faktor eksternal yang sangat penting dan strategis bagi pengembangan indutri kecil makanan ringan, maka dilakukan analisis faktor strategi internal dengan menyusun suatu table EFAS (Eksternal Faktor Analysis Summary) 
Tabel 2. Eksternal Faktor Analysis Summary (EFAS) Pengembangan Industri Makanan Ringan di Kota Payakumbuh

\begin{tabular}{|c|l|c|c|c|}
\hline No & \multicolumn{1}{|c|}{ Faktor Strategis Eksternal } & Bobot & Rating & $\begin{array}{c}\text { Skor } \\
\text { Total }\end{array}$ \\
\hline A & Peluang & & & \\
\hline 1 & Peluang Pasar & 0,098 & 4 & 0,392 \\
\hline 2 & Kemajuan Teknologi & 0,144 & 3 & 0,432 \\
\hline 3 & Pertumbuhan Ekonomi & 0,174 & 3 & 0,522 \\
\hline 4 & Keragaman produk yang dihasilkan & 0,136 & 3 & 0,408 \\
\hline & Jumlah & 0,552 & 13 & 1,754 \\
\hline B & Ancaman & & & \\
\hline 1 & Tingkat Inflasi & 0,167 & 3 & 0,501 \\
\hline 2 & Persaingan Produk sejenis & 0,152 & 3 & 0,456 \\
\hline 3 & Selera konsumen & 0,129 & 3 & 0,387 \\
\hline & Jumlah & 0,448 & 9 & 1,344 \\
\hline
\end{tabular}

Dari perpotongan keempat garis faktor kekuatan, kelemahan, peluang dan ancaman maka didapatkan koordinat $(0.0485 ; 0.205)$ yaitu :

$\underline{\text { Skor Kekuatan - skor Kelemahan ; Skor Peluang-Skor Ancaman }}$

$$
\begin{gathered}
\frac{1.486-1.389}{2} ; \frac{1.754-1.344}{2} \\
(0,0485 ; 0.205)
\end{gathered}
$$

Analisa SWOT yang dilakukan sebelumnya dapat digunakan sebagai dasar dalam penentuan strategi pengembangan industri kecil ke depan. SWOT matrik dibangun berdasarkan hasil analisis faktor-faktor strategis baik internal maupun eksternal yang terdiri dari faktor kekuatan, kelemahan, peluang dan ancaman. Hasil analisa pada matrik SWOT diperoleh Koordinat $(0,0485 ; 0,205)$ yang mana koordinat ini masuk pada kuadran I, yakni mendukung Strategi yang Agresif.

\subsubsection{Formulasi Strategi Pengembangan Industri Makanan Ringan di Kota Payakumbuh}

Hasil analysis SWOT berupa matrik yang terdiri dari empat kuadran dimana masingmasing kuadran merupakan perpaduan strategi antara faktor internal (kekuatan dan kelemahan) dan faktor eksternal (Peluang dan Ancaman) (F.R. David, 2006)

Pada kuadran pertama dihasilkan beberapa strategi dengan memanfaatkan unsur kekuatan untuk merebut peluang yang tersedia. Strategi ini lazim disebut sebagai S-O Strategy dan ada yang bahkan menyebutnya sebagai Strategi Ekspansif (Growth Oriented Strategi). Berdasarkan analysis, strategi yang diformulasikan pada kuadran pertama ini adalah (i) optimalisasi peningkatan produksi (ii) perluasan pasar dan (iii) pengembangan kawasan industry kecil.

Pada kuadran kedua dihasilkan beberapa strategi pengembangan dengan memanfaatkan kekuatan yang dimiliki untuk mengurangi ancaman yang datang dari luar. Strategi ini biasa disebut sebagai $S$-T Strategy yang lebih bersifat Strategi Defensif terhadap ancaman yang datang dari luar. Strategi yang diformulasikan pada kuadran kedua ini adalah (i) peningkatan inovasi dan pemanfaatan teknologi dalam produksi (ii) pengembangan produk makanan.

Analog dengan kuadran sebelumnya, pada kuadran ketiga dihasilkan strategi pengembangan dengan mengatasi kelemahan yang ada untuk merebut peluang yang tersedia, karena itu strategi ini juga disebut sebagai $W$-O Strategy yang lebih bersifat Internal Adjustment Oriented. Strategi yang diformulasikan pada kuadran ketiga ini adalah (i) pengembangan kemitraan (ii) pembinaan dan pelatihan dari pemerintah. 


\begin{tabular}{|c|c|c|}
\hline EFAS & \begin{tabular}{|l} 
Strengths (S) \\
1 Ketersediaan Bahan Baku \\
2.Potensi Tenaga Kerja Lokal yg \\
tersedia banyak \\
3.Kebijakan pemerintah yang \\
kuat utk pengembangan IKM \\
4.Pelaksanaan Pembinaan
\end{tabular} & $\begin{array}{l}\text { Weakness (W) } \\
\text { 1. Kualitas produk rendah } \\
\text { 2.Teknologi yang digunakan } \\
\text { sederhana } \\
\text { 3. Kemampuan permodalan } \\
\text { yang terbatas } \\
\text { 4. Manajemen Usaha } \\
\text { 5. Kelembagaan Pengusaha } \\
\text { 6. Informasi Pasar }\end{array}$ \\
\hline $\begin{array}{ll} & \text { Opportunities }(\mathbf{0}) \\
\text { 1. } & \text { Peluang Pasar } \\
\text { 2. } & \text { Pertumbuhan } \\
& \text { Ekonomi } \\
\text { 3. } & \text { Kemajuan teknologi } \\
\text { 4. } & \text { Keragaman Produk }\end{array}$ & \begin{tabular}{ll} 
& \multicolumn{1}{c}{ Strategi SO } \\
1. & Optimalisasi Peningkatan \\
& Produksi \\
& $(\mathrm{S} 1, \mathrm{~S} 2,01,02,03,04)$ \\
2. & Perluasan Pasar \\
& $(\mathrm{S} 1, \mathrm{~S} 2, \mathrm{~S} 3, \mathrm{~S} 4,01,03,04)$ \\
3. & Pengembangan Kawasan \\
& Industri Kecil \\
& $(\mathrm{S} 1, \mathrm{~S} 2, \mathrm{~S} 3, \mathrm{~S} 4,01,02,03)$ \\
\end{tabular} & \begin{tabular}{ll}
\multicolumn{1}{c}{ Strategi WO } \\
1. & Pengembangan Kemitraan \\
(W1,W2,W3,W4,W5,04) \\
2. \\
Pembinaan dan Pelatihan \\
dari Pemerintah \\
$(\mathrm{W} 1, \mathrm{~W} 2, \mathrm{~W} 3,01,02)$
\end{tabular} \\
\hline $\begin{array}{l}\text { Threats (T) } \\
\text { 1.Persaingan produk } \\
\text { import } \\
\text { 2.Selera konsumen yg } \\
\text { cendrung pada produk } \\
\text { import } \\
\text { 3.Tingkat Inflasi }\end{array}$ & \begin{tabular}{ll} 
& \multicolumn{1}{c}{ Strategi ST } \\
1. & Peningkatan Inovasi dan \\
& Pemanfaatan Teknologi \\
& Produksi ( S2,S3,T1,T2,T4) \\
2. & Pengembangan Produk \\
& Makanan (S1,S2,T1,T2,T3)
\end{tabular} & $\begin{array}{l}\text { Strategi WT } \\
\text { 1. Peningkatan Kualitas dan } \\
\text { daya saing produk } \\
\text { ( W1,W2,W3,W5,T1,T2,T3) } \\
\text { 2. Penguatan dan } \\
\text { pengembangan pemasaran } \\
\text { produk (W1,W2,W3,W4,W5, } \\
\text { T1,T2) }\end{array}$ \\
\hline
\end{tabular}

Pada kuadran keempat dapat dihasilkan strategi pengembangan dengan mengatasi kelemahan internal yang ada untuk mengurangi ancaman yang dating dari luar. Strategi ini biasa disebut dengan W-T Strategy yang lebih bersifat Self Defence Strategi. Strategi yang diformulasikan pada kuadran keempat tersebut adalah (i) peningkatan kualitas dan daya saing produk (ii) penguatan dan pengembangan pemasaran produk.

Strategi yang diformulasikan dalam analisis SWOT diurutkan berdasarkan total skor dari interaksi dari faktor-faktor yang mempengaruhinya untuk mendapatkan prioritas strategi pengembangan industri kecil makanan ringan di Kota Payakumbuh:

a. Optimalisasi Peningkatan Produksi

Dilakukan dengan berbagai kegiatan sebagai berikut:

1) Memfasilitasi pengusaha dengan menginvestasikan asset modal dan teknologi yang modern untuk meningkatkan produktifitas produksi;

2) Peningkatan akses permodalan dan investasi

3) Memfasilitasi pengusaha dalam pengurusan persyaratan izin usaha dan persyaratan lainnya dalam upaya peningkatan mutu dan keamanan pangan.

b. Perluasan Pasar

Dilakukan kegiatan sebagai berikut:

1) Menggalang kerjasama regional dalam pemasaran produk

2) Pemanfaatan secara optimal LO/Agen pemasaran yang telah didirikan di Kota Batam sebagai upaya pengenalan produk ke negara tetangga. 
c. Pengembangan Kawasan industri kecil

Dilakukan dengan dengan kegiatan sebagai berikut :

1) Penyediaan areal lahan untuk kawasan industri

2) Pemberian kemudahan dalam proses perizinan bagi usaha dan investor di kawasan industri tersebut

3) Melengkapi segenap fasilitas untuk menciptakan one stop service di kawasan industri (listrik, Kios, Waserda, rest area, BBM dan sebagainya)

4) Penyediaan fasilitas untuk mendukung pengawasan mutu produk hasil industri (Labor uji mutu)

5) Penyediaan fasilitas bagi industri dan pemasaran hasil produksi

d. Peningkatan inovasi dan pemanfaatan teknologi dalam produksi

Strategi peningkatan inovasi dan pemanfaatan teknologi ini dilakukan dengan kegiatan sebagai berikut :

1) Fasilitasi pelatihan dan penyediaan teknologi modern dalam berproduksi

2) Peningkatan kerjasama dengan lembaga akademis dalam upaya pengembangan riset dan development sebagai upaya meningkatkan mutu dan inovasi produk

e. Pengembangan Produk Makanan

Strategi ini dilakukan dengan kegiatan sebagai berikut

1) Pengembangan rekayasa teknologi terapan untuk mengembangkan produk bernilai tambah

2) Pengenalan produk yang bernilai tambah yang inovatif kepada pengusaha tradisional

3) Mendorong dan mendukung sector swasta dalam mendiversifikasikan produk makanan

f. Pengembangan Kemitraan

Dilakukan dengan kegiatan sebagai berikut

1) Meningkatkan kerjasama kemitraan antara industri besar dengan industri kecil makanan ringan dengan dukungan dan fasilitasi dari pemerintah.

2) Mencari bapak angkat bagi industri kecil yang potensial tapi sulit untuk meningkatkan usahanya

g. Pembinaan dan Pelatihan dari Pemerintah

Kegiatan yang dapat dilakukan :

1) Memfasilitasi industri kecil dalam pemanfaatan teknologi modern dalam upaya untuk meningkatkan produktifitas produksi

2) Penyediaan informasi pasar tentang kondisi dan permintaan pasar sehingga pengusaha dapat segera mengantasipasi permintaan dan selera pasar

h. Peningkatan Kualitas dan Daya Saing Produk

Dapat dilakukan beberapa kegiatan sebagai berikut :

1) Pengembangan sarana dan prasarana produksi sejak proses pemilihan bahan baku sampai dengan pengolahan produk dan pemasarannya

2) Pemantapan sistem sertifikasi dan standarisasi produk

3) Pelatihan dan penyuluhan tentang tatacara proses pengolahan bahan baku sampai pada proses produksi dan pemasaran

4) Peningkatan akses permodalan dan investasi

i. Penguatan dan Pengembangan Pemasaran Produk

Strategi penguatan dan pengembangan pemasaran produk dilakukan dengan kegiatan sebagai berikut :

1) Mendorong dan mendukung sector swasta dalam upaya pengembangan dan promosi perdagangan eksport kearah pemasaran interregional

2) Perluasan pasar internasional

3) Meningkatkan dan penguasaan informasi tentang pesaing, segemen pasar dan selera konsumen tentang jenis produk sehingga perubahan selera pasar luar negeri dapat diantisipasi 
Setelah dihasilkan berbagai strategi yang dirumuskan dari hasil analisis SWOT, dilakukan analisis Quantitative Strategic Planning Matrix (QSPM) untuk mendapatkan prioritas strategi pengembangan industri kecil makanan ringan di Kota Payakumbuh. Keuntungan dengan menggunakan matriks QSPM adalah strategi-strategi dapat diperiksa secara berurutan dan bersamaan, serta tidak ada batas untuk jumlah strategi yang dapat dievaluasi secara sekaligus (Zulkarnaen, H. O., 2013). Berdasarkan analisis QSPM dihasilkan bahwa strategi yang menjadi prioritas dalam pengembangan industri makanan ringan adalah sebagai berikut:

a. Pengembangan Kawasan Industri Kecil

b. Peningkatan Mutu dan Daya Saing Produk

c. Pengembangan Produk

d. Perluasan Pasar

Tabel dibawah ini memperlihatkan prioritas alternative strategi yang dapat diterapkan dalam rangka meningkatkan kinerja dan daya saing industri dan daya saing produk makanan Kota Payakumbuh.

Tabel 4. Matriks Perencanaan Strategi Kuantitatif (QSPM) Industri Kecil Makanan Ringan di Kota Payakumbuh

\begin{tabular}{|c|c|c|c|c|c|c|c|c|c|}
\hline \multirow{2}{*}{\begin{tabular}{|c|} 
Alternatif Strategi \\
Faktor Kunci
\end{tabular}} & \multirow[b]{2}{*}{ Bobot } & \multicolumn{2}{|c|}{$\begin{array}{c}\text { Pengembangan } \\
\text { Kawasan } \\
\text { Industri } \\
\end{array}$} & \multicolumn{2}{|c|}{$\begin{array}{c}\text { Peningkatan } \\
\text { Mutu \& } \\
\text { Dayasaing } \\
\end{array}$} & \multicolumn{2}{|c|}{$\begin{array}{l}\text { Pengembangan } \\
\text { Produk }\end{array}$} & \multicolumn{2}{|c|}{ Perluasan Pasar } \\
\hline & & $\begin{array}{l}\text { Nilai } \\
\text { daya } \\
\text { tarik }\end{array}$ & Total & $\begin{array}{l}\text { Nilai } \\
\text { Daya } \\
\text { Tarik }\end{array}$ & Total & $\begin{array}{l}\text { Nilai } \\
\text { daya } \\
\text { tarik }\end{array}$ & Total & $\begin{array}{l}\text { Nilai } \\
\text { Daya } \\
\text { Tarik }\end{array}$ & Total \\
\hline \multicolumn{10}{|l|}{ Peluang } \\
\hline $\begin{array}{l}\text { Peluang Pasar } \\
\text { Dalam/luar negeri }\end{array}$ & 0,098 & 4 & 0,392 & 4 & 0,392 & 4 & 0,392 & 4 & 0,392 \\
\hline Kemajuan Teknologi & 0,144 & 4 & 0,576 & 4 & 0,576 & 4 & 0,576 & 4 & 0,576 \\
\hline $\begin{array}{l}\text { Pertumbuhan } \\
\text { Ekonomi }\end{array}$ & 0,174 & 3 & 0,522 & 3 & 0,522 & 3 & 0,522 & 3 & 0,522 \\
\hline $\begin{array}{l}\text { Keragaman produk } \\
\text { yang dihasilkan }\end{array}$ & 0,136 & 4 & 0,544 & 3 & 0,408 & 3 & 0,408 & 3 & 0,408 \\
\hline \multicolumn{10}{|l|}{ Ancaman } \\
\hline Tingkat Inflasi & 0,167 & 4 & 0,668 & 4 & 0,668 & 3 & 0,501 & 3 & 0,501 \\
\hline $\begin{array}{l}\text { Persaingan Produk } \\
\text { sejenis }\end{array}$ & 0,152 & 4 & 0,608 & 4 & 0,608 & 4 & 0,608 & 3 & 0,456 \\
\hline Selera konsumen & 0,129 & 3 & 0,387 & 3 & 0,387 & 3 & 0,387 & 3 & 0,387 \\
\hline \multicolumn{10}{|l|}{ Kekuatan } \\
\hline $\begin{array}{l}\text { Ketersediaan bahan } \\
\text { baku }\end{array}$ & 0,127 & 4 & 0,508 & 3 & 0,381 & 4 & 0,508 & 4 & 0,508 \\
\hline $\begin{array}{l}\text { Ketersediaan Tenaga } \\
\text { kerja }\end{array}$ & 0,112 & 4 & 0,448 & 3 & 0,336 & 3 & 0,336 & 3 & 0,336 \\
\hline Kebijakan pemerintah & 0,112 & 4 & 0,448 & 4 & 0,448 & 3 & 0,336 & 3 & 0,336 \\
\hline $\begin{array}{l}\text { Pelaksanaan } \\
\text { pembinaan }\end{array}$ & 0,102 & 3 & 0,306 & 4 & 0,408 & 4 & 0,408 & 3 & 0,306 \\
\hline \multicolumn{10}{|l|}{ Kelemahan } \\
\hline Kualitas produk & 0,088 & 4 & 0,352 & 4 & 0,352 & 4 & 0,352 & 4 & 0,352 \\
\hline Penggunaan Teknologi & 0,107 & 4 & 0,428 & 4 & 0,428 & 4 & 0,428 & 4 & 0,428 \\
\hline Permodalan & 0,083 & 3 & 0,249 & 3 & 0,249 & 3 & 0,249 & 3 & 0,249 \\
\hline Manajemen Usaha & 0,083 & 3 & 0,249 & 3 & 0,249 & 3 & 0,249 & 3 & 0,249 \\
\hline $\begin{array}{l}\text { Kelembagaan } \\
\text { Pengusaha }\end{array}$ & 0,102 & 3 & 0,306 & 3 & 0,306 & 3 & 0,306 & 3 & 0,306 \\
\hline Informasi Pasar & 0,083 & 4 & 0,332 & 3 & 0,249 & 3 & 0,249 & 3 & 0,249 \\
\hline Jumlah & 0.577 & & 7 & & 6,967 & & 6,815 & & 6,561 \\
\hline
\end{tabular}


Sesuai dengan hasil analisis potensi dan perkembangan, maka strategi pengembangan kawasan industri kecil ditujukan untuk mengoptimalkan pembinaan dan pengembangan dalam upaya peningkatan daya saing produk makanan ringan, memudahkan pembinaan dari pemerintah, informasi pasar akan lebih cepat didapat, ada jaminan akan sumber bahan baku dan pasar serta ongkos angkut akan lebih minim.

\section{Kesimpulan dan Rekomendasi}

\subsection{Kesimpulan}

Berdasarkan hasil penelitian ini dapat ditarik kesimpulan sebagai berikut :

a. Faktor-faktor yang menandakan tingkat daya saing dari industri kecil dan produknya di Kota Payakumbuh meliputi faktor : pendidikan pengusaha, pendidikan dan ketrampilan tenaga kerja, permodalan, ketersediaan input, teknologi, profitabilitas usaha.

b. Peluang pengembangan didukung dengan ketersediaan bahan baku dan trend permintaan terhadap produk makanan ringan yang selalu meningkat dari daerah lain;

c. Analisa SWOT menghasilkan posisi industri makanan ringan berada pada kuadran I (skor yang diperoleh : 0,0485; 0,205), dengan strategi yang cocok adalah strategi agresif, yaitu dengan cara mengoptimalkan kekuatan yang ada. Sedangkan dari hasil pemaduan faktor-faktor internal dengan faktor-faktor eksternal dalam matrik SWOT diperoleh 9 strategi yaitu : (1) Optimalisasi Peningkatan Produksi, (2) Strategi Perluasan Pasar, (3) Strategi Peningkatan Inovasi dan Pemanfaatan Teknologi Dalam Produksi, (4)Strategi Pengembangan Produk, (5) Strategi Pengembangan Kemitraan, (6) Strategi Pembinaan dan Pelatihan Dari Pemerintah, (7) Strategi Pengembangan Kawasan Industri, (8) Strategi Peningkatan Kualitas dan Daya Saing Produk serta (9) Strategi Penguatan dan Pengembangan Pemasaran Produk Makanan Ringan.

\subsection{Rekomendasi}

a. Hal-hal yang diperlukan dalam pengembangan UMKM Kota Payakumbuh yakni agar Pemerintah Daerah dapat melakukan :

1) Menciptakan iklim usaha yang sehat dan kondusif serta proaktif

2) Program mendorong tumbuh dan berkembangnya program-program yang mendukung pemantapan pemasaran produk-produk lokal seperti trading house, pondok promosi dll.

b. Sedangkan bagi pengusaha UMKM disarankan :

1) Menerapkan manajemen usaha yang lebih baik dengan melakukan konsep perencanaan dan pengelolaan keuangan serta melengkapi izin usaha.

2) Pemakaian bahan baku yang berkualitas, penerapan teknologi tepat guna, menjaga dan meningkatkan mutu produk .

3) Strategi pengembangan pemasaran dengan menerapkan strategi marketing mix

\section{Daftar Pustaka}

David, F.R. (2006). "Strategic Management". Consepts and Cases, (10th ed.). Ed.Francis Marion University Florence.

David, Fred R. (2011). Manajemen Strategi. Salemba Empat.

David, R. F. (2004). Manajemen Strategi Konsep Terjemahan (edisi kese). Prehalindo.

Kuncoro Mudrajad. (2003). Metode Riset Untuk Bisnis \& Ekonomi. PT. Dwi Chandra Wacana.

Rangkuti, F. (2013). Analisis SWOT : Teknik Membedah Kasus Bisnis. PT. Gramedia Pustaka

RPJMD Kota Payakumbuh Tahun 2017-2022.

Tambunan, Tulus, T. H. (2009). Usaha Kecil Dan Menengah Di Indonesia. Salemba.

Undang-Undang No 20 tahun 2008 Tentang Usaha Mikro, Kecil dan Menengah.

Zulkarnaen, H. O., S. (2013). Analisis Strategi Pemasaran pada Usaha Kecil Menengah (UKM) Makanan Ringan (Studi Penelitian UKM Snack Barokah di Solo). Diponegoro Journal of Management. 